\title{
Additions and corrections to the new Catalogue of Palaearctic Cerambycidae (Coleoptera) edited by I. Löbl and A. Smetana, 2010. Part II
}

\author{
Аополнения и исправления к новому каталогу палеарктических \\ Cerambycidae (Coleoptera) под редакщией I. Löbl и A. Smetana, 2010. \\ Часть II
}

\author{
M.L. Danilevsky \\ M.А. Аанилевский
}

\begin{abstract}
A. N. Severtzov Institute of Ecology and Evolution, Russian Academy of Sciences, Leninsky prospect 33, Moscow 119071, Russia. E-mail: danilevskyml@rambler.ru,danilevsky@cerambycidae.net

Институт Проблем Экологии и Эволюции им. А.Н. Северцова РАН, Ленинский пр. 33, Москва 119071, Россия.
\end{abstract}

KEY WORDS: Cerambycidae, taxonomy, new combinations, new synonyms, new names, Palearctic.

КЛЮЧЕВЫЕ СЛОВА: Cerambycidae, таксономия, новые сочетания, новые названия, Палеарктика.

ABSTRACT. About seventy misprints, wrong combinatiobns, wrong geographical records, wrong references, wrong status of certain names, wrong synonyms, wrong authotships and dates of certain names, wrong original combinations, wrong spelling of several names and so on are fixed. Sometimes unavailable names were publisjed as available. Missing names, geographical data and references are added. Molorchus sterbai Adlbauer, 1988 from Libanon is accepted as valid name. New synonyms are established: Diastocera Dejean, 1835 = Analeptes Gistl, 1848, syn.n.; Leptura rufoannulata $($ Pic, 1933) = Leptura fisheriana Gressitt, 1938, syn.n.; Molorchus sterbai Adlbauer, 1988 = Glaphyra azri Sama, Rapuzzi \& Kairouz, 2010, syn.n.

РЕЗЮМЕ. Исправлено около семидесяти разнообразных ошибок: опечаток, неправильных сочетаний, синонимов, ошибочных географических указаний, ошибочно указанных дат публикации названий и их авторов, ошибочных оригинальных сочетаний, написаний и т.д. Указаны несколько непригодных названий, опубликованных как пригодные. Добавлены пропущенные названия, публикации и географические данные. Molorchus sterbai Adlbauer, 1988 из Ливана принят в качестве валидного названия. Предложены новые синонимы: Diastocera Dejean, 1835 = Analeptes Gistl, 1848, syn.n.; Leptura rufoannulata (Pic, 1933) = Leptura fisheriana Gressitt, 1938, syn.n.; Molorchus sterbai Adlbauer, $1988=$ Glaphyra azri Sama, Rapuzzi \& Kairouz, 2010, syn.n.

The new Catalogue of Palaearctic Cerambycidae (Coleoptera) edited by I. Löbl and A. Smetana [2010] was prepared with the participation of 11 authors: K. Adlbauer, M.L. Danilevsky, A. Drumont, L. Hubweber, Z. Komiya,
I. Löbl, J. Morati, P. Rapuzzi, G. Sama, A. Smetana and A. Weigel. The system of the authorship was rather complicated. It was partly arranged in taxonomy way and partly in geographical. So, such groups as Prioninae or Dorcadionini had own authors, while other authors were responsible for a certain geographical areas. The taxa of Western Palaearctic, for example, were arranged by G. Sama and I. Löbl, while M.L. Danilevsky and A. Smetana were responsible for the taxa from Russia and countries of the former USSR, and Mongolia. So, the authorship of all Cerambycidae genera, which are distributed in West Europe and in Russia was in fact mutual (with the exception of Dorcadionini). Each author had his own point of view on the system of each subfamily and each genus. So, the editors had to create a generally accepted system on the base of several different positions. As a result I. Löbl and A. Smetana took part in the arrangement of nearly each genus.

The necessity to join together several rather different texts (certain portions were presented to the editors in last moment before the publication) was the primary cause of many mistakes and misprints. Several names are published contemporary in different genera, the status of others was wrongly interpreted, many names were wrongly spelled or with wrong authors and dates, several geographical records were so strange, that could be simply misprints, many references were wrong, several publications were referred with two different names and so on. The main purpose of the present publication is to fix direct mistakes.

The references to the present article include only the publications absent in the references to the Catalog. The references inside the text of the present article to the publications included in the references to the Catalog have same letters after the number of the year as in the Catalog. 


\section{PAGE47}

PRINTED (TWO TIMES):

Poecilium alni elburs ense Holzschuh, 1977

MUST BE:

Poecilium alni elburzense Holzschuh, 1977

\section{PAGES 85-252}

All names proposed by Holzschuh [1995] are published in the Catalog as "Holzschuh, 1965"

PRINTED:

p.85 - mellina Holzschuh, 1965: 5 A: YUN

p.85 - perforans Holzschuh, 1965: 6 A: YUN

p.85 - rufobrunnea Holzschuh, 1965: 6 A: SCH

p.98 - tenebraria Holzschuh, 1965: 10 (Anoploderomorpha) A: YUN

p.109 - congesta Holzschuh, 1965: 11 A: YUN

p.109 - eucera Holzschuh, 1965: 12 A: YUN

p.117 - genus Thrangalia Holzschuh, 1965: 10 type spe-

cies Thrangalia diaboliella Holzschuh, 1995

diaboliella Holzschuh, 1965: 11 A: YUN

p.124 - wewalkai Holzschuh, 1965: 9 A: TR

wittmeri Holzschuh, 1965: 9 A: TR

p.131 — palligera Holzschuh, 1965: 8 A: YUN

p.143 - genus Pufujia Holzschuh, 1965: 16 type species

Pufujia luteosignata $\mathrm{Pu}, 1991$

p.153 - eximium Holzschuh, 1965: 35 A: YUN

p.156 - fallaciosum Holzschuh, 1965: 19 A: YUN ORR

p.162 - consona Holzschuh, 1965: 18 A: NP SD

p.163 - sausai Holzschuh, 1965: 31 A: YUN

p.163 - atricornis Holzschuh, 1965: 33 A: BT

p.163 — giganteus Holzschuh, 1965: 34 A: YUN

p.163 - modicatus Holzschuh, 1965: 33 A: YUN

p.164 - lucens Holzschuh, 1965: 28 A: SCH

p.172 — jendeki Holzschuh, 1965: 41 A: YUN

p.173 — parilis Holzschuh, 1965: 39 A: YUN

p.173 - sausai Holzschuh, 1965: 40 A: YUN

p.174 — decolorata Holzschuh, 1965: 38 A: YUN

p.178 - decora Holzschuh, 1965: 39 A: YUN

p.186 - arenbergeri Holzschuh, 1965: 14 E: IT (Sardegna)

p.190 - unanimis Holzschuh, 1965: 26 A: SCH

p.193 - fumigatum Holzschuh, 1965: 23 A: YUN

p.202 - clarinus Holzschuh, 1965: 23 A: YUN

p.204 - aethiops Holzschuh, 1965: 25 (Euchlanis) A: YUN

p.249 - maceki Holzschuh, 1965: 41 A: TR

p.252 - scrobicolle morulum Holzschuh, 1965: 42 A: TR

MUST BE:

p.85 - mellina Holzschuh, 1995: 5 A: YUN

p.85 - perforans Holzschuh, 1995: 6 A: YUN

p.85 - rufobrunnea Holzschuh, 1995: 6 A: SCH

p.98 - tenebraria Holzschuh, 1995: 10 (Anoploderomorpha) A: YUN

p.109 - congesta Holzschuh, 1995: 11 A: YUN

p.109 - eucera Holzschuh, 1995: 12 A: YUN

p.117 - genus Thrangalia Holzschuh, 1995: 10 type spe-

cies Thrangalia diaboliella Holzschuh, 1995

diaboliella Holzschuh, 1995: 11 A: YUN

p.124 - wewalkai Holzschuh, 1995: 9 A: TR

wittmeri Holzschuh, 1995: 9 A: TR

p.131 — palligera Holzschuh, 1995: 8 A: YUN

p.143 - genus Pufujia Holzschuh, 1995: 16 type species

Nortia luteosignata $\mathrm{Pu}, 1991$

p.153 - eximium Holzschuh, 1995: 35 A: YUN

p.156 - fallaciosum Holzschuh, 1995: 19 A: YUN ORR

p.162 - consona Holzschuh, 1995: 18 A: NP SD

p.163 - sausai Holzschuh, 1995: 31 A: YUN p.163 - atricornis Holzschuh, 1995: 33 A: BT

p.163 — giganteus Holzschuh, 1995: 34 A: YUN

p.163 - modicatus Holzschuh, 1995: 33 A: YUN

p.164 - lucens Holzschuh, 1995: 28 A: SCH

p.172 — jendeki Holzschuh, 1995: 41 A: YUN

p.173 - parilis Holzschuh, 1995: 39 A: YUN

p.173 - sausai Holzschuh, 1995: 40 A: YUN

p.174 - decolorata Holzschuh, 1995: 38 A: YUN

p.178 — decora Holzschuh, 1995: 39 A: YUN

p.186 - arenbergeri Holzschuh, 1995: 14 E: IT (Sardegna)

p.190 - unanimis Holzschuh, 1995: 26 A: SCH

p.193 - fumigatum Holzschuh, 1995: 23 A: YUN

p.202 — clarinus Holzschuh, 1995: 23 A: YUN

p.204 - aethiops Holzschuh, 1995: 25 (Euchlanis) A: YUN

p.249 - maceki Holzschuh, 1995: 41 A: TR

p.252 - scrobicolle morulum Holzschuh, 1995: 42 A: TR

\section{PAGE 92}

PRINTED:

besikanus Fairmaire, 1855: 318 (Prionus) E: AL BU GR MC MD TR YU A: CY TR

batelkai Sláma, 1996: 75 (Prionus)

tangerianus Sláma, 1996: 76 (Prionus) NOTE:

Prionus tangerianus Slama, 1996 was described from Morocco on the base of a single old male. But newly collected males are also known. Sama [1998] mentioned a male (from coll. of A. Drumont) labelled "Maroc, Moyen Atlas, VI.1996".

Another male is known with the label: "NE Marocco, Atlas Mts., Houria vill., 6.7.1951, Lorenc coll.”— see: http://www.cerambycidae.cz/beetlespages/Mesoprio_tangerianus.htm

Sama [1998] declared: "I regard collecting labels of these specimens quite suspect; it is extremely unlikely that professional entomologists such as Antoine, Rungs, Kocher and many others never recorded this species, all the more that it is very easily attracted to light." Drumont [2010 - personal message] maitained Sama's opinion, that all labels of Mesoprionus for Africa were false.

\section{PAGE 96 AND 109}

PRINTED:

(p. 96)

genus Acanthoptura Fairmaire, 1894a: 224 type species Acanthoptura spinipennis Fairmaire, 1894

denticollis Holzschuh, 1993a: 17 A: SCH impressicollis Pic, 1920f: 117 (Leptura) A: SCH YUN

pallescens Holzschuh, 1993a: 20 (Parastrangalis) A: GAN SHA

and (p. 109)

genus Parastrangalis Ganglbauer, 1889a: 57 type species Leptura potanini Ganglbauer, 1889

palleago Holzschuh, 1998: 25 A: HUB palpalis Holzschuh, 1991c: 29 A: SCH

MUST BE

$$
\text { (p. 96) }
$$

genus Acanthoptura Fairmaire, 1894a: 224 type species Acanthoptura spinipennis Fairmaire, 1894

denticollis Holzschuh, 1993a: 17 A: SCH

impressicollis Pic, 1920f: 117 (Leptura) A: SCH YUN

and

(p. 109):

genus Parastrangalis Ganglbauer, 1889a: 57 type species Leptura potanini Ganglbauer, 1889 
palleago Holzschuh, 1998: 25 A: HUB

pallescens Holzschuh, 1993a: 20 A: GAN SHA

palpalis Holzschuh, 1991c: 29 A: SCH

...

NOTE:

Parastrangalis pallescens Holzschuh, 1993a is quite a normal Parastrangalis. Its transfer to Acanthoptura was just a nonsense (and not reflected in the «New Acts»).

\section{PAGE 96}

PRINTED:

tabacicolor erythropus Gebler, 1841b: 612 (Leptura) A: ES

FE JA KZ MG NT WS

MUST BE:

tabacicolor erythropus Gebler, 1841 b: 612 (Leptura) A: ES

FE JA KZ MG NC NE SC WS

\section{PAGE 96}

PRINTED:

fusca Matsushita, 1930: 24

NOTE:

The name must be excluded from the Catalog as unavailble. It was introduced as Alosterna tabacicolor var. fusca Matsushita, 1930 (Mt. Kurodake, Hokkaido) together with Alosterna tabacicolor var. bivittis: Matsushita, 1930 (Mt. Kurodake, Hokkaido) - two variations from one locality, so "its author expressly gave it infrasubspecific rank" according to the Article 45.6.4. of ICZN.

\section{PAGE 96}

PRINTED:

tabacicolor tabacicolor DeGeer, 1775: 139 (Leptura) E: AL

AU BE BH BU BY CR CT CZ DE EN FI FR GB GE GR

HU IR IT KZ LA LS LT LU MC MD NE NL NR NT PL

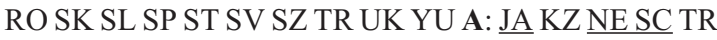
WS

MUST BE:

tabacicolor tabacicolor DeGeer, 1775: 139 (Leptura) E: AL AU BE BH BU BY CR CT CZ DE EN FI FR GB GE GR HU IR IT KZ LA LS LT LU MC MD NE NL NR NT PL RO SK SL SP ST SV SZ TR UK YU A: KZ TR WS

\section{PAGE 98}

PRINTED:

rufipes rufipes Schaller, 1783: 296 (Leptura) E: AB AR AU BH BU BY CR CT CZ EN FR GE GB GG GR HU IT LA LT MD NT PL RO SK SL SP ST SV SZ YU UK A: ES IN KZ

MUST BE:

rufipes rufipes Schaller, 1783: 296 (Leptura) E: AB AR AU BH BU BY CR CT CZ EN FR GE GB GG GR HU IT LA LT MD NT PL RO SK SL SP ST SV SZ YU UK A: ES IN KZ TR

\section{PAGE 99 AND 112}

PRINTED (P. 99):

genus Corennys Bates, 1884: 224 type species Corennys sericata Bates, 1884

Pseudocorennys Pic, 1952d: 47 type species Pyrocalymma diversicornis Pic, 1947 (= Pyrocalymma conspicua Gahan, 1906

brevipennis prescutellaris Pic, 1947c: 17 (Pyrocalymma) A: CH ORR

caduca Holzschuh, 1998: 28 A: HUB

cardinalis Fairmaire, 1887a: 131 (Ephies) A: YUN

circellaris Holzschuh, 1992: 12 A: SCH conspicua Gahan, 1906a: 89 (Pyrocalymma) A: BT HAI HEB SCH SHA XIZ YUN ORR

diversicornis Pic, 1947c: 17 (Pyrocalymma)

sensitiva Holzschuh, 1998: 29 A: YUN

sanguinea Kano, 1933a: 271 A: HAI TAI

sericata Bates, 1884: 225 A: HEB JA NE SC

taiwana Hayashi, 1963d: 130 A: TAI

AND (p. 112)

genus Pyrocorennys N. Ohbayashi \& Niisato, 2009: 160 type species Pyrocalymna latipennis Pic, 1927

latipennis latipennis Pic, 1927b: 26 (Pyrocalymna) A: YUN ORR

brevipennis Pic, 1946: 17 (Pyrocalymna) [no such pages in the referenses!]

latipennis taiwanensis Hayashi, 1969a: 61 (Formosopyrrhona) A: TAI

MUST BE (P.99):

genus Corennys Bates, 1884: 224 type species Corennys sericata Bates, 1884

Pseudocorennys Pic, 1952d: 47 type species Pyrocalymma diversicornis Pic, 1947 (= Pyrocalymma conspicua Gahan, 1906

caduca Holzschuh, 1998: 28 A: HUB

cardinalis Fairmaire, 1887a: 131 (Ephies) A: YUN

circellaris Holzschuh, 1992: 12 A: SCH

conspicua Gahan, 1906a: 89 (Pyrocalymma) A: BT HAI HEB SCH SHA XIZ YUN ORR

diversicornis Pic, 1947c: 17 (Pyrocalymma)

sensitiva Holzschuh, 1998: 29 A: YUN

sanguinea Kano, 1933a: 271 A: HAI TAI

sericata Bates, 1884: 225 A: HEB JA NE SC

taiwana Hayashi, 1963d: 130 A: TAI and (p. 112)

genus Pyrocorennys N. Ohbayashi \& Niisato, 2009: 160 type species Pyrocalymna latipennis Pic, 1927

latipennis latipennis Pic, 1927b: 26 (Pyrocalymna) A: YUN ORR

brevipennis Pic, 1947c: 17 (Pyrocalymna)

latipennis taiwanensis Hayashi, 1969a: 61 (Formosopyrrhona) A: TAI

NOTE:

According to Ohbayashi \& Niisato [2009: 161]: "Pyrocorennys latipennis prescutellaris Pic, 1946" (described as "Pyrocalimna brevipennis var. prescutellaris Pic, 1946: 17") is known only from North Vietnam.

10. PAGES 102-103

PRINTED: (P. 102)

genus Judolia Mulsant, 1863: 496 type species Leptura sexmaculata Linnaeus, 1758

Julodia Pic, 1891b: 12 type species Leptura sexmaculata Linnaeus, 1758

japonica Tamanuki, 1942: 179 (Strangalia) A: JA

parallelopipeda Motschulsky, 1860b: 146 (Grammoptera)

E: NT A: ES FE JA MG NC SC WS "Korea"

abbreviata Motschulsky, 1875: 143 (Grammoptera)

multidisjuncta Pic, 1914c: 5

shirarakensis Matsumura, 1911a: 137 (Leptura)

and (p. 103)

genus Judolia, nomen dubium

rufimembris Pic, 1917g: 3 (Leptura) A: "Siberia or."

MUST BE (P. 102):

genus Judolia Mulsant, 1863: 496 type species Leptura sexmaculata Linnaeus, 1758

Julodia Pic, 1891b: 12 type species Leptura sexmaculata Linnaeus, 1758 
japonica Tamanuki, 1942: 179 (Strangalia) A: JA

parallelopipeda Motschulsky, 1860b: 146 (Grammoptera)

E: NT A: ES FE JA MG NC SC WS "Korea"

abbreviata Motschulsky, 1875: 143 (Grammoptera)

multidisjuncta Pic, 1914c: 5

rufimembris Pic, 1917g: 3 (Leptura)

shirarakensis Matsumura, 1911a: 137 (Leptura) NOTE:

The type investigation of Leptura (Judolia) sexmaculata var. rufimembris Pic, 1917 preserved in Pic's collection in Paris allows to identify the half-colored specimen (a female) as Judolia parallelopipeda (Motschulsky, 1860).

\section{PAGE 104}

PRINTED:

duodecimguttata duodecimguttata Fabricius, 1801 b: 353 A:

ES FE FUJ HEI HEN JA JIL KZ MG NC NMO QIN SC SCH SHX WS ZHE

bisbijuncta Pic, 1904d: 14

kapfereri Pic, 1912j: 89

mediojuncta Pic, 1902d: 10 (Strangalia)

mediosemijuncta Pic, 1927e: 13 (Strangalia)

subobliterata Pic, 1927e: 10 (Strangalia)

duodecimguttata rufoannulata Pic, 1933b: 26 (Strangalia)

A: $\mathrm{SCH}$

fisheriana Gressitt, 1938a: 45 A: FUJ HUB SCH

MUST BE:

duodecimguttata Fabricius, 1801b: 353 A: ES FE FUJ HEI

HEN JA JIL KZ MG NC NMO QIN SC SCH SHX WS

ZHE

bisbijuncta Pic, 1904d: 14

kapfereri Pic, 1912j: 89

mediojuncta Pic, 1902d: 10 (Strangalia)

mediosemijuncta Pic, 1927e: 13 (Strangalia)

subobliterata Pic, 1927e: 10 (Strangalia)

rufoannulata Pic, 1933b: 26 (Strangalia) A: FUJ HUB SCH fisheriana Gressitt, 1938a: 45

NOTE:

According to Heyrovsky [1934] Leptura duodecimguttata ssp. rufoannulata (Pic, 1933) is in fact a good species.

A comparison of the original description of Strangalia duodecimguttata var. rufoannulata Pic, 1933 (redescribe as Leptura rufoannulata by Heyrovsky, 1934) show its identity to Leptura fisheriana Gressitt, 1938, so Leptura rufoannulata $($ Pic, 1933 $)=$ Leptura fisheriana Gressitt, 1938, syn.n.

\section{PAGE 104}

PRINTED:

gradatula Holzschuh, 2006a: 216 A: SHA

MUST BE:

gradatula Holzschuh, 2006a: 216 A: GAN SCH SHA

According to the original description.

\section{PAGE 108}

PRINTED:

erraticus erraticus Dalman, 1817a: 490 (Leptura) E: AB AL

AR AU BH BU BY CR CT CZ FR GE GG GR HU IT MC MD PL RO SK SL SP ST SZ TR UK YU A: IN SY TR MUST BE:

erraticus erraticus Dalman, 1817a: 490 (Leptura) E: AB AL

AR AU BH BU BY CR CT CZ FR GE GG GR HU IT KZ MC MD PL RO SK SL SP ST SZ TR UK YU A: IN KZ SY TR

NOTE:

See: Kostin [1973] and Zhuravlev [1914].

\section{PAGE 111}

PRINTED:

genus Pseudovadonia Lobanov, Danilevsky \& Murzin, 1981: 787 type species Leptura livida Fabricius, 1777

livida desbrochersi Pic, 1891k: xvi (Vadonia) E: AB AR GG A: TR

corallipes Reitter, 1894f: 247 (Leptura)

livida livida Fabricius, 1777: 233 (Leptura) E: AL AR AU BE BU BH BY CR CT CZ DE EN FR GB GE GG GR HU IR IT KZ LA LT MC MD NE NL NT PL PT RO SK SL SP ST SZ TR UK YU A: ES IS KZ LE TR SY WS XIN bicarinata N. Arnold, 1869: 137 (Grammoptera) pastinacae Panzer, 1795: 275 (Leptura) pecta K. Daniel \& L. Daniel, 1891: 38 (Leptura)

MUST BE:

genus Pseudovadonia Lobanov, Danilevsky \& Murzin, 1981: 787 type species Leptura livida Fabricius, 1777

livida bicarinata N. Arnold, 1869: 137 (Grammoptera) E: AB AR BY CT EN GG KZ LA LT NT PL ST UK A: ES IR KZ KI TR WS XIN

livida desbrochersi Pic, 1891k: xvi (Vadonia) E: AB AR GG A: TR corallipes Reitter, 1894f: 247 (Leptura)

livida livida Fabricius, 1777: 233 (Leptura) E: AL AU BE BU BH CR CZ DE FR GB GE GR HU IR MC MD NE NL ?PT RO SK SL ? SP SZ TR UK YU A: ?IS ?LE ?TR ?SY pastinacae Panzer, 1795: 275 (Leptura)

livida pecta K. Daniel \& J. Daniel, 1891: 38 (Leptura) E: IT NOTE:

P. l. livida (Fabricius, 1777), described from near Kiel (Germany), is characterized by strongly erect straight dorsal pronotal setae (see "Galleri" www.cerambycidae.net). Such form of pronotal pubescence can be observed in most populations from West Europe (available specimens are from: France, Germany, Czechia, Hungary, Moldavia, West Ukraine Transcarpathia, Bulgaria, Greece), as well as from West Turkey (Antalia).

P. l. bicarinata (N. Arnold, 1869), described from near Mogilev (East Belorussia) is characterized by obliquely erect dorsal pronotal setae (see "Gallery" www.cerambycidae.net). Such form of pronotal pubescence can be observed all over Russia, in most of Ukraine territory, in Baltic countries, in Poland, in Transcaucasia with neighbour regions of Turkey, in Kazakhstan and Kirgizia. "Leptura l. var. bicarinata (N. Arnold, 1869)" was already accepted as a taxon for European Russia [K. Daniel \& J. Daniel, 1891].

The type locality of $P$. livida pecta (K. Daniel \& J. Daniel, 1891) was not definitely mentioned in the original description, neither holotype was designated. The authors called the corresponding form as "Bozener Form" and specially described specimens from near "Bozen" - now Bolzano in North Italy (Trentino - Alto Adige). But they included in the area of their "Leptura livida var. pecta": Piedmont (Italy), Digne (France), Lugano (Switzerland), as well as Spain, "Kleinasiaen", "Kaukasus" and Siberia ("Irkutsk"), so the lectotype from near Bolzano is necessary to be designated for the fixation of the taxon. Specimens from North Italy (available specimens are from Bolzano and Trento - coll. of M. Egger; Fanano near Modena - author's collection) are characterized by strongly recumbent dorsal pronotal setae (see "Galleri" www.cerambycidae.net). Such form of pronotal pubescence is not known to me in any other area. It seems to be an endemic of North Italy. The specimens from Cental and South Italy have obliquely erect dorsal pronotal setae and so similar to P. l. bicarinata and must be described as another subspecies, 
as well as populations from Iberian Peninsula and Near East must be also described as new subspecies. The record of the species for Iran was published by Gfeller [1972]: "Chalus (Now Shar) Mazandaran"

\section{PAGE 113}

\section{PRINTED:}

bifasciata bifasciata O. F. Müller, 1776: 93 (Leptura) E: AB AL AR AU BE BH BU BY CR CT CZ EN FR GE GG GR HU IT LA LS LT LU MC MD NL NT PL PT RO SK SL SP ST SZ TR UK YU A: ES IN IQ KZ TR WS XIN albarracina Wagner, 1927a: 45 (Leptura) cruciata Olivier, 1795: 7 (Leptura) ferruginipes Pic, 1895d: 76 (Strangalia) immaculata Pic, 1889b: 55 (Strangalia) lanceolata Mulsant \& Rey, 1863: 177 (Strangalia) nigriventris Pic, 1891b: 15 (Strangalia) sedakovi Mannerheim, 1852b: 307 (Stenura) ustulata Laicharting, 1784: 157 [HN] (Leptura)

bifasciata limbiventris Reitter, 1898a: 21 (Strangalia) E: GG A: TR

bifasciata nigrosuturalis Reitter, 1895a: 88 (Strangalia) A: LE SY TR

hybridula Reitter, 1901h: 188 (Strangalia) E: PT SP atriventris Pic, 1905a: 8 (Leptura) [DA] atronotata Pic, $1918 \mathrm{~d}: 5$

intermedia Holzschuh, 2006a: 219 E: GR

MUST BE:

bifasciata bifasciata O. F. Müller, 1776: 93 (Leptura) E: AB AL AR AU BE BH BU BY CR CT CZ EN FR GE GG GR HU IT LA LS LT LU MC MD NL NT PL PT RO SK SL SP ST SZ TR UK YU A: ES IN IQ KZ TR WS XIN albarracina Wagner, 1927a: 45 (Leptura) cruciata Olivier, 1795: 7 (Leptura) immaculata Pic, 1889b: 55 (Strangalia) nigriventris Pic, 1891b: 15 (Strangalia) sedakovi Mannerheim, 1852b: 307 (Stenura) ustulata Laicharting, 1784: 157 [HN] (Leptura)

bifasciata ferruginipes Pic, 1895d: 76 (Strangalia) A: TR bifasciata intermedia Holzschuh, 2006a: 219 E: GR BG bifasciata lanceolata Mulsant \& Rey, 1863: 177 (Strangalia) E: FR SP

bifasciata limbiventris Reitter, 1898a: 21 (Strangalia) E: GG A: TR

bifasciata nigrosuturalis Reitter, 1895a: 88 (Strangalia) A: LE SY TR

hybridula Reitter, 1901h: 188 (Strangalia) E: PT SP atriventris Pic, 1905a: 8 (Leptura) [DA] atronotata Pic, 1918d: 5

NOTE:

A lot of specimens of Stenurella bifasciata intermedia Holzschuh, 2006a (including many females, which are not described yet) were collected by A. Napolov in Greece from South Peloponnesus (Mani Peninsula) to Struma valley in Bulgaria in May-June 2010. Relatively large pronotal punctation of $S$. bifasciata intermedia Holz. (the main distinguishing character of the species according to the oryginal description) is really a little larger than in specimens from Central Europe, but just same as in many south populations from Italy to Caucasus. Females (see "Galleri" in www.cerambycidae.net) of $S$. $b$. intermedia Holz. are very similar to $S$. b. bifasciata, but black elytral design is a little reduced.

The taxon described as Strangalia lanceolata Mulsant \& Rey, 1863 from «L'Espagne» on the base of females with elytra widely darkened along suture is a well formed Iberian subspe- cies S. bifasciata ssp. lanceolata (Mulsant \& Rey, 1863). $S$. b. lanceolata penetrates in South France. Two females with the label: «France, Pyrénées Orientales, Prades, 24-30.6.1986, Schimmel leg.» are preserved in my collection.

Populations, which contain specimens with pale-orange legs, represent a well delimited subspecies described as Strangalia bifasciata var. ferruginipes Pic, 1895 from «Bitlis». Stenurella bifasciata ssp. ferruginipes (Pic, 1895) is represented in my materials from Mardin (Hop Geçidi) and Bitlis (Tatvan environs).

\section{PAGE 116}

PRINTED:

semirufa Kraatz, 1880b: 376 (Leptura)

MUST BE:

semirufula Kraatz, 1880b: 376 (Leptura)

NOTE:

According to the original description.

\section{PAGE 116}

PRINTED:

variicornis Dalman, 1817a: 482 (Leptura) E: CT NT PL UK

\section{A: ES FE KZ MG NC SC WS}

MUST BE:

variicornis Dalman, 1817a: 482 (Leptura) E: BY CT EN LA

LT NT PL UK A: ES FE JP KZ MG NC NE NO SC WS

\section{PAGE 116}

PRINTED:

genus Stictoleptura nomen dubium

silbermanni Lefebvre, 1835: 303 (Leptura) A: "Syrie Mont Liban" NOTE:

According to Sama et al. [2010] Leptura silbermanni Lefebvre, 1835 was the first name for Stictoleptura heydeni (Ganglbauer, 1888); it was proposed to be regarded as "nomen oblitum" following the Article 23.9.2 of ICZN. But the obligated condition of that article is the existence of 25 publications with the protected name by at least 10 authors for the last 50 years. Without such a condition the name Stictoleptura silbermanni (Lefebvre, 1835) must be accepted as valid. In fact the type of Leptura silbermanni Lefebvre, 1835 is not known, so the real nature of the described taxon rests doubtful, and for the stability of the current nomenclature it is better to leave it as "nomen dubium".

\section{PAGE 117}

PRINTED:

bipunctata adusta Kraatz, 1859: 97 (Leptura) E: HU MC RO SK SL

litigiosa Mulsant, 1863: 564

bipunctata bipunctata Fabricius, 1781: 245 (Leptura) E: CT ST A: KZ WS

beckeri Pic, 1941d: 14 (Leptura)

fischeri Zubkov, 1829: 167 (Leptura)

laterimaculata Motschulsky, 1875: 142 (Leptura)

sareptana Pic, 1941d: 15

bipunctata mulsantiana Plavilstshikov, 1936: 341 (Leptura) E: MD RO ST UK

bipunctata puchneri Holzschuh, 2007: 183 E: ST UK

bipunctata steveni Sperk, 1835: 158 (Leptura) E: HU MD SK SL UK

bilitigiosa Pic, 1941d: 15 [DA]

globicollis Desbrochers des Loges, 1870c: 127 (Leptura)

[DA]

rufonotata Pic, 1926d: 10 (Leptura) 
MUST BE:

bipunctata adusta Kraatz, 1859: 97 (Leptura) E: HU MC RO SK SL

litigiosa Mulsant, 1863: 564

rufonotata Pic, 1926d: 10 (Leptura)

bipunctata bipunctata Fabricius, 1781: 245 (Leptura) E: CT ST A: KZ WS

beckeri Pic, 1941d: 14 (Leptura)

fischeri Zubkov, 1829: 168 (Leptura)

sareptana Pic, 1941d: 15

bipunctata globicollis Desbrochers des Loges, 1870c: 127 (Leptura) E: MD RO ST UK

mulsantiana Plavilstshikov, 1936: 341 (Leptura) bilitigiosa Pic, 1941d: 15

bipunctata laterimaculata Motschulsky, 1875: 141 (Leptura) E: UK (Crimea)

puchneri Holzschuh, 2007: 183

bipunctata steveni Sperk, 1835: 158 (Leptura) E: HU MD SK SL ST UK

NOTE:

Leptura laterimaculata Motschulsky, 1875 was described from Crimea ("Tauride") on the base of a male with black elytra, each with small lateral yellow spots. The holotype (see "Galleri" in www.cerambycidae.net) of the taxon (head, prothorax and several legs are absent) is preserved in Zoological Museum of Moscow University. It is undoubtedly a form of Vadonia bipunctata (because of typical elytral design and numerous erect setae on hind femur), which was recently described as V. puchneri Holzschuh, 2007. So, Leptura laterimaculata Motschulsky, 1875 = Vadonia puchneri Holzschuh, 2007, syn.n.

Leptura (Vadonia) bipunctata var. rufonotata Pic, 1926d was described from "Hongrie"

Leptura globicollis Desbrochers des Loges, 1870c was described from "Kustendjé (Turquie)" [Constanşa, Romania], so very close to Izmail - the the type locality of Leptura (Vadonia) bipunctata mulsantiana Plavilstshikov, 1936, so Leptura globicollis Desbrochers des Loges, $1870=$ L. $($ Vadonia) bipunctata mulsantiana Plavilstshikov, 1936.

Leptura steveni Sperk, 1835 was described from Podolia (north-west Ukraine). Vadonai bipunctata steveni Sperk, 1835 is distributed eastwards to North Caucasus. The specimens of the subspecies have very rough pronotal punctation similar to $V$. unipunctata and $V$. b. laterimaculata Motschulsky, 1875 They differs from the later by usuall elytral design: pale elytral color is often very dark and elytral apices are often contrastly black. Males of $V$. b. steveni Sperk, 1835 (as well as in $V$. $b$. globicollis Desbrochers des Loges, 1870) have sometimes only one spine in hind tibia. Such structure can be also observed in all other subspecies of V.bipunctata, but very rare.

\section{PAGE 117}

PRINTED:

bitlisiensis Chevrolat, 1882: 59 E: AR A: TR

MUST BE:

bitlisiensis Chevrolat, 1882: 59 E: AR AB A: TR

NOTE:

The species was recorded for Nakhichevan Republic of Azerbajdzhan by Plavilstshikov [1948].

\section{PAGE 117}

PRINTED:

cribricollis Pic, 1889b: 20 [mispaginated: 5]

MUST BE:

cribricollis Pic, 1889b: 20 [mispaginated: 5] (Leptura)

\section{PAGE 118}

PRINTED:

unipunctata unipunctata Fabricius, 1787: 157 (Leptura) [NP]

E: AB AR AU BH BU CR CT CZ FR GG GR HU IT KZ MD PL RO SB SK SL SP ST TR UK A: KZ TR obscurepilosa Pic, 1892q: 1xxxiv pilosa Forster, 1771: 44 (Leptura) [NO]

MUST BE:

unipunctata unipunctata Fabricius, 1787: 157 (Leptura) [NP]

E: AB AR AU BH BU CR CT CZ FR GG GR HU IT KZ MD PL RO SB SK SL SP ST TR UK A: KZ TR

obscurepilosa Pic, 1892q: 1xxxiv

pilosa Forster, 1771: 44 (Leptura) [NO]

uninstigmata Pic, 1891b: 9 (Leptura)

NOTE:

A taxononomy Act for the protection of Leptura unipunctata Fabricius, 1787 is not published in the Catalog. According to Sama [2008]: Leptura unipunctata Fabricius, 1787 ("nomen protectum") = Leptura pilosa Forster, 1771 ("nomen oblitum"). But 25 publications by 10 authors for the last 50 years [ICZN Art. 23.9.1.2] were not listed, so the action can not be regarded as valid.

Here is the list of 25 publications, where the name "unipunctata Fabricius, 1787" was used as valid: Bartenev, 2004, 2009; Danilevsky, 2009; Danilevsky \& Miroshnikov, 1985; Esjunin \& Kozminyh, 1992; Zagaikevich, 1991, 1979; Isaev, 2007; Isaev et al., 2004; Isaev \& Magdeev, 2003; Kaliuzhnaja et al., 2000; Kostin, 1968, 1973; Kryzhanovsky, 1974; Lobanov et al., 1981; Magdeev, 1996, 2003; Martynov \& Pisarenko, 2004; Mikhailov, 1999; Miroshnikov, 1998; Naumov, 1994; Negrobov et al., 2005; Pisarenko, 1999; Plavilstshikov, 1965; Romadina, 1954; Shapovalov et al., 2006.

\section{PAGE 119}

PRINTED:

dentipes Mulsant, 1842a: 209

MUST BE:

dentipes Mulsant, 1842a: 209 ( $\underline{\text { Toxotus }}$ )

\section{PAGE 124}

PRINTED:

carneola Schrank, 1798: 698 (Leptura)

MUST BE:

carneola Schrank, 1798: $\underline{696}$ (Leptura)

\section{PAGE 124}

PRINTED:

minuta Gebler, 1832: 69 (Pachyta) A: ES FE GUX HEB HEI

HEN JA JIL JIX LIA NC NIN NMO SC SHA SHN SHX

ZHE

criocerina Bates, 1873: 194 (Acmaeops)

japonica Pic, 1907d: 20 (Acmaeops)

MUST BE:

minuta criocerina Bates, 1873: 194 (Acmaeops) A: JA

japonica Pic, 1907d: 20 (Acmaeops)

minuta minuta Gebler, 1832: 69 (Pachyta) A: ES FE GUX

HEB HEI HEN JIL JIX LIA NC NIN NMO SC SHA SHN SHX ZHE

NOTE:

The synonyms of Pachyta minuta Gebler, 1832 (described from Transbaicalia) and Acmaeops criocerina Bates, 1873 (described from Japan) were generally accepted by all recent Japan publications, but continental and Japan populations are rather different. First of all most of Japan specimens have partly or totally red abdomen, while such form is 
unknown in Russia (from Baikal to Kamchatka and Sakhalin). It is known from South Korea as rare aberration. So, at least subspecies rank of two names must be accepted. But in fact Dinoptera minuta (Gebler, 1832) and Dinoptera criocerina (Bates, 1873) must be different species, because D. minuta penetrates far northwards in the continent (to about Kamchatka Peninsula), but D. criocerina is known from South Japan only (absent in Hokkaido).

\section{PAGE 133}

PRINTED:

nubecula Bergsträsser, 1778: 25 (Cerambyx)

MUST BE:

nubecula Bergsträsser, 1778: 26 (Cerambyx)

\section{PAGE 134}

\section{PRINTED:}

meridianus Linnaeus, 1758: 398 (Leptura) E: AL AU BE BH

BU BY CR CT CZ DE EN FI FR GB GE GR HU IR IT

LA LS LT MC MD NL NR NT PL RO SK SL SP ST SV

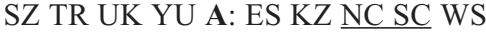

\section{MUST BE:}

meridianus Linnaeus, 1758: 398 (Leptura) E: AL AU BE BH

BU BY CR CT CZ DE EN FI FR GB GE GR HU IR IT

LA LS LT MC MD NL NR NT PL RO SK SL SP ST SV SZ TR UK YU A: ES KZ WS

NOTE:

Several old records of Stenocorus meridianus for Korea were connected with $S$. amurensis.

The records of $S$. meridianus for Gansu and Shaanxi [Hua, 2002] were quite doubtful and adequtely not accepted in the Catalog.

\section{PAGE 135}

PRINTED:

ambustum Heyden, 1877a: 394

NOTE:

The name was introduced as Rhamnusium bicolor var. ambustum Heyden, 1877 among other variations from same locality: "Drei Linden" bei Soden, so it must be excluded as unavailable.

\section{PAGE 137}

PRINTED:

ferus Mulsant, 1839: 64 (Criocephalus) E: AB AR AU BE BH BU BY CR CT CZ DE EN FR GB GE GG GR HU IR IT LA LT LU MA MC MD NL NT PL PT RO SK SL SP ST SV SZ UK N: AG MO MR TU A: ES CY FE IS JO KZ TR WS MUST BE:

ferus Mulsant, 1839: 64 (Criocephalus) E: AB AR AU BE BH BU BY CR CT CZ DE EN FR GB GE GG GR HU IR IT LA LT LU MA MC MD NL NT PL PT RO SK SL SP ST SV SZ UK N: AG MO MR TU A: ES CY FE IS JO KZ NO NE TR WS

30. PAGE 143

PRINTED:

genus Pufujia Holzschuh, 1965: 16 type species Pufujia luteosignata $\mathrm{Pu}, 1991$

MUST BE:

genus Pufujia Holzschuh, 1995: 16 type species Nortia luteosignata $\mathrm{Pu}, 1991$

\section{PAGE 153}

PRINTED:

elbursense Holzschuh, 1977a: 128
MUST BE:

elburzense Holzschuh, 1977a: 128

\section{PAGE 155}

PRINTED:

macropus Germar, 1824: 514 (Callidium) E: AB AR AU BH BU BY CR CT CZ GE GG HU LA MD PL RO SK SL ST SZ TR UK YU A: IN TR

MUST BE:

macropus Germar, 1824: 514 (Callidium) E: AB AR AU BH BU BY CR CT CZ GE GG HU LA LT MD PL RO SK SL ST SZ TR UK YU A: IN TR

NOTE:

Ropalopus macropus was recorded for Lithuania by Inokaitis [2004, 2009].

\section{PAGE 156}

PRINTED:

johannis johannis Baeckmann, 1922: 24 A: KI XIN

MUST BE:

johannis johannis Baeckmann, 1922: 24 A: KI

NOTE:

Turanium johannis johannis Baeckmann, 1922 (described from Talas Ridge) was recorded for Xinjiang (Sinkiang) by Hua [2002]. The species is impossible for China. The record could be connected with $T$. badenkoi Danilevsky, 2001e described from the north slope of Zailiysky Alatau, or with a new species.

\section{PAGE 156}

PRINTED:

tribe Callidiopini Lacordaire, 1868

genus Ceresium Newman, 1842d: 322 type species Ceresium raripilum Newman, 1842

Diatomocephala Blanchard, 1853: 266 type species Diatomocephala maculicollis Blanchard, 1853

Paraceresium Matsushita, 1932: 71 type species Paraceresium saipanicum Matsushita, 1932

Pneumida J. Thomson, 1864a: 191 type species Pneumida argenteofasciata J. Thomson, 1864 NOTE:

According to Holzschuh [1995: 16] Pneumida J. Thomson, $1864 \mathrm{a}$ is a valid name in Cerambycini.

\section{PAGE 157}

PRINTED:

genus Parasalpinia Hayashi, 1962c: 4 type species Parasalpinia kojimai Hayashi, 1962

kojimai Hayashi, 1962c: 4 A: JA (Ryukyus) TAI

laosensis Gressitt \& Rondon, 1970: 102 (Salpinia) A: YUN ORR

genus Salpinia Pascoe, 1869: 536 type species Salpinia diluta Pascoe, 1869

laosensis Gressitt \& Rondon, 1970: 102 A: HAI YUN ORR MUST BE:

genus Parasalpinia Hayashi, 1962c: 4 type species Parasalpinia kojimai Hayashi, 1962

kojimai Hayashi, 1962c: 4 A: JA (Ryukyus) TAI

laosensis Gressitt \& Rondon, 1970: 102 (Salpinia) A: HAI YUN ORR NOTE:

Genus Salpinia Pascoe, 1869 absent in Palaearctic Region. According to Niisato [2002]: "Salpinia laosensis agrees with the characteristics of Parasalpinia and should be transferred to that genus." 


\section{PAGE 159}

\section{PRINTED:}

cerdo cerdo Linnaeus, 1758: 392 E: AB AL AR AU BE BH

BU BY CR CT CZ FR GBi GE GG GR HU IR IT LA LU MA MC MD NL PL PT RO SK SL SP ST SZ TR UK YU N: MO A: IN IQ IS JO LE SY TR

MUST BE:

cerdo cerdo Linnaeus, 1758: 392 E: AB AL AR AU BE BH BU BY CR CT CZ FR GBi GE GG GR HU IR IT LA LU MA MC MD NL PL RO SK SL ST SV SZ TR UK YU N: MO A: IN IQ IS JO LE SY TR

\section{PAGE 159}

PRINTED:

manderstjaernae Mulsant \& Godart, 1855a: 180

MUST BE:

manderstjernae Mulsant \& Godart, $1855 \mathrm{~b}: 280$ [=1855a: 180]

\section{PAGE 167}

PRINTED:

gratiosus gratiosus Marseul, 1868: 203 (Clytus) A: IS LE SY gratiosus sparsus Reitter, 1886: 67 (Clytus) A: TR

MUST BE:

gratiosus gratiosus Marseul, 1868: 203 (Clytus) A: IS LE gratiosus sparsus Reitter, 1886: 67 (Clytus) $\underline{\text { E: GR A: SY }}$ TR NOTE:

According to Sama et al. [2010]: "La forme type, connue du Liban, est remplacée au Sud de la Turquie, en Syrie et dans l'île de Rhodes: environs de Arhagelos (espèce nouvelle pour la faune de Grèce et de l'Europe) par la sous-espèce C. gratiosus sparsus (Reitter, 1886) à coloration élytrale entièrement noire."

\section{PAGE 167}

PRINTED:

latofasciatus Motschulsky, 1861b: 41 (Clytus) A: ES FE FUJ

GAN HEB HEI HEN JIL LIA MG NC NMO SC SHA SHN SHX ZHE

chasanensis Tsherepanov, 1982a: 175

motschulskyi Ganglbauer, 1887a: 135 (Clytanthus)

MUST BE:

motschulskyi Ganglbauer, 1887a: 135 (Clytus) [RN] A: ES

FE FUJ GAN HEB HEI HEN JIL LIA MG NC NMO SC

SHA SHN SHX ZHE

chasanensis Tsherepanov, 1982a: 175

latofasciatus Motschulsky, 1861b: 41 (Clytus) [HN] NOTE:

Clytus latofasciatus Motschulsky, $1861 \mathrm{~b}$ is a junior homonym of Clytus latifasciatus Fischer von Waldhein, 1832 See Art. 58.12 about different connecting vowels in compound words.

\section{PAGE 169}

PRINTED:

varius varius O. F. Müller, 1766: 188 (Leptura) E: AB AL

AR AU BH BU BY CR CT CZ FR GBi GE GG GR HU IT LS LT MA MC MD NL PL RO SK SL SP ST SZ TR UK YU A: JIA KZ TR WS

MUST BE:

varius varius O. F. Müller, 1766: 188 (Leptura) E: AB AL AR AU BH BU BY CR CT CZ FR GBi GE GG GR HU IT LS LT MA MC MD NL PL RO SK SL SP ST SZ TR UK YU A: KZ TR WS

\section{PAGE 178}

PRINTED:

genus Rhaphuma Pascoe, 1858: 240 type species Rhaphuma placida Pascoe, 1858

Arcyophorus Gemminger, 1872: 2938 type species Arcyphorus histrio Chevrolat, 1863

Arcyphorus Chevrolat, 1863b: 287 type species Arcyphorus histrio Chevrolat, 1863

Raphuma J. Thomson, 1864: 192 type species Clytus quadricolor Laporte \& Gory, 1836

\section{MUST BE:}

genus Rhaphuma Pascoe, 1858: 240 [RN] type species Clytus quadricolor Laporte \& Gory, 1836

Arcyophorus Gemminger, 1872: 2938 [unjustified emendation]

Arcyphorus Chevrolat, 1863b: 287 type species Arcyphorus histrio Chevrolat, 1863

Raphuma J. Thomson, 1861: 221 [unjustified emendation] Rhaphium A.White, 1855: 289 [HN] type species Clytus quadricolor Laporte \& Gory, 1836

42. PAGE 180

PRINTED:

genus Sclethrus Newman, 1842a: 247 type species Ibidion amoenum Gory, 1833

MUST BE:

genus Sclethrus Newman, 1842a: 247 type species Sclethrus newmany Chevrolat, 1863

Neocollyroides Schultze, 1920:196 type species Neocollyroides macregory Schultze, 1920 NOTE:

According to Han \& Niisato [2009].

\section{PAGE 186}

PRINTED:

campestris Faldermann, 1835c: 435 (Callidium) E: CT MD PLi RO ST UK A: ANH ES FE GAN GUI HEB HEI HEN HUB HUN IN JA JIA JIL JIX KI KZ LIA MG NC NMO QIN SC SCH SHA SHN SHX TD TM UZ XIN XIZ YUN ZHE ORR

MUST BE:

campestris Faldermann, 1835c: 435 (Callidium) E: $\underline{\mathrm{AB} \text { AR }}$ CT CZ MD PLi RO SK ST UK A: ANH ES FE GAN GUI HEB HEI HEN HUB HUN IN JA JIA JIL JIX KI KZ LIA MG NC NMO QIN SC SCH SHA SHN SHX TD TM UZ

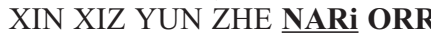
NOTE: 2010].

The species was recorded for Canada [Grebennikov et al.,

44. PAGE 190

Missing name: Molorchus abieticola Holzschuh, 2007: 218

Must be accepted as: Molorchus (Coenoptera) abieticola Holzschuh, 2007: 218 E: TR

45. PAGE 190

PRINTED:

tenuitarsis Holzschuh, 1981: 97 (Molorchus) A: TR

sterbai Adlbauer, 1988: 277 (Molorchus)

MUST BE:

sterbai Adlbauer, 1988: 277 A: LE

azri Sama, Rapuzzi \& Kairouz, 2010: 151 (Glaphyra)

tenuitarsis Holzschuh, 1981: 97 A: TR

NOTE:

Molorchus kiesenwetteri ab. sterbai Heyrovsky, 1936 described from Lebanon was not available; it was validated as 
"Molorchus sterbai Heyrovsky, 1936" by Adlbauer [1988] (without description - just a name in the list of his specimens - so, fits to the Article 13.1.2). The holotype of the name is a specimen of ab. sterbai from Heyrovsky's collection, but not a specimen identified so by Adlbauer.

The taxon was described once more as Glaphyra azri Sama, Rapuzzi \& Kairouz, 2010 also from Lebanon, so Molorchus sterbai Adlbauer, 1988 = Glaphyra azri Sama, Rapuzzi \& Kairouz, 2010, syn.n.

\section{PAGE 192}

PRINTED:

genus Chinobrium Gressitt, 1937c: 449 type species Chino-

brium mediofasciatum Gressitt, 1937

aegrotum Holzschuh, 1982a: 67 (Obrium) A: NP

mediofasciatum Gressitt, 1937c: 449 A: JIX ORR

opacum Holzschuh, 1984c: 348 (Stenhomalus) A: BT ORR MUST BE:

The correct combination is:

Obrium aegrotum Holzschuh, 1982a: 67 A: NP

\section{PAGE 195}

PRINTED:

genus Allotraeus Bates, 1877: 36 type species Allotraeus sphaerioninus Bates, 1877

subgenus Pseudallotraeus Pic, 1923a: 13 type species Pseudallotraeus rufescens Pic, 1923

rufescens Pic, 1923a: 13 A: JA SC TAI

and

genus Nysina Gahan, 1906a: 153 type species Sphaerion orientale A. White, 1853

Neosphaerion Schwarzer, 1925a: 21 type species $\mathrm{Ne}$ osphaerion asiaticum Schwarzer, 1925

Pseudallotraeus Pic, 1923a: 13 type species Pseudallotraeus rufescens Pic, 1923

rufescens Pic, 1923a: 13 (Pseudallotraeus) A: JA TAI japonica K. Ohbayashi, 1936a: 13 NOTE:

So, the name Pseudallotraeus Pic, 1923 was used twice in different genera with different rank. According to Niisato [2007]: Pseudallotraeus Pic, 1923 is a synonym of Nysina Gahan, 1906, which is a subgenus of Allotraeus Bates, 1877, so the second case of the Catalog is acceptable.

\section{PAGE 196}

PRINTED:

halodendri ephippium Steven \& Dalman, 1817: 157 (Cerambyx) E: ST UK A: KZ

MUST BE:

halodendri ephippium Steven \& Dalman, 1817: 157 (Cerambyx) E: AL BU ST UK KZ A: KZ NOTE:

Asias halodendri was recorded for Albania [Muraj, 1960] and Bulgaria [Angelov, 1995].

49. PAGE 202

PRINTED:

alpina alpina Linnaeus, 1758: 392 (Cerambyx) E: AB AL AU AR BH BU BY CR CT CZ FR GE GG GR HU LS MC PL RO SK SL SP ST SV SZ UK YU A: TR MUST BE:

alpina alpina Linnaeus, 1758: 392 (Cerambyx) E: AB AL AU AR BH BU BY CR CT CZ FR GE GG GR HU IT LS MC PL RO SK SL SP ST SZ UK YU A: TR

\section{PAGE 207}

PRINTED:

Neoacanthocinus Dillon, 1956: 230 type species Acanthocinus obsoletus Olivier, 1837

MUST BE:

According to the original publicaion,

Neacanthocinus Dillon, 1956: 230 type species Acanthocinus obsoletus Olivier, 1837

\section{PAGE 215}

PRINTED:

kirbyi Gyllenhal, 1817: 186 (Saperda) E: AB AL AR BH BU CR FR GG GR HU IT MC MD RO SK SP ST TR UK YU A: IN IS SY TM

MUST BE:

kirbyi Gyllenhal, 1817: 186 (Saperda) E: AB AL AR BH BU

CR CT FR GG GR HU IT MC MD RO SK SP ST TR UK YU A: IN IS SY TM $\underline{\text { TR }}$ NOTE:

The species is well known from Samara and Ulianovsk regions of Central Russia, as well as from Turkey.

\section{PAGE 227}

PRINTED:

sokotrensis Téocchi, Jiroux \& Sudre, 2004: 22 (Arasbosybrinus) A: YE (Suqutra)

MUST BE:

sokotrensis Téocchi, Jiroux \& Sudre, 2007: 22 (Arasbosybrinus) A: YE (Suqutra)

\section{PAGE 239}

PRINTED:

genus Diastocera J. Thomson, 1857: 183 type species Lamia tricincta Duncan, 1835 (=Lamia wallichi Hope, 1831) Thysia J. Thomson, 1860: 96 type species Lamia wallichi Hope, 1831

Thysiotes J. Thomson, 1868: 201 [RN] type species Lamia wallichi Hope, 1831

MUST BE:

genus Thysia J. Thomson, 1860: 96 type species Lamia wallichi Hope, 1831

Thysiotes J. Thomson, 1868: 201 [RN] type species Lamia wallichi Hope, 1831 NOTE:

The author of Diastocera is Dejean [1835: 342] with Lamia trifasciata Fabricius, 1775: 174 as type species (monotypy) - African genus. Lamia trifasciata Fabricius, 1775 is the type species of African Analeptes Gistl, 1848: 430

So, Diastocera Dejean, 1835: 342 = Analeptes Gistl, 1848: 430, syn.n. Thysia J. Thomson, 1860: 96 (type species Lamia wallichi Hope, 1831) is valid.

54. PAGE 239

PRINTED:

savioi Yen, 1933: 165

NOTE:

The reference to the publication by Yen [1933] absent in the References to the Catalog. According to Hua [2002] it was:

Yen Chia-hsien, 1932: A new species of Cerambycidae from Kwangsi. Peking Natural History Bulletin 7(2): 165-166. 55. PAGE 240

PRINTED:

Tylophorus Blessig, 1873: 213 type species Tylophorus wulffusi Blessig, 1873 
and

wulffusi Blessig, 1873: 215 (Thylophorus)

MUST BE:

Thylophorus Blessig, 1873: 213 type species Thylopho-

rus wulffiusi Blessig, 1873

and

wulffiusi Blessig, 1873: 215 (Thylophorus)

NOTE:

According to the original description.

56. PAGE 242

PRINTED:

fulvum fulvum Scopoli, 1763: 53 (Cerambyx) E: AU CZ HU

SK SL UK

freyi Tippmann, 1958b: 158

frontale Mulsant \& Rey, 1863: 154

kulzeri Tippmann, 1958b: 158

nigripenne Fleischer, 1894: 121

sanguinolentum Scopoli, 1772: 99 (Prionus)

MUST BE:

fulvum fulvum Scopoli, 1763: 53 (Cerambyx) E: AU CZ HU

SK SL UK

freyi Tippmann, 1958b: 158

frontale Mulsant \& Rey, 1863: 154

kulzeri Tippmann, 1958b: 158

nigripenne Fleischer, 1894: 121

rugipenne Tippmann, 1958b: 155

sanguinolentum Scopoli, 1772: 99 (Prionus)

57. PAGES 243, 246 AND 247

PRINTED (p. 243):

arenarium marsicanum Fracassi, 1905: 112 E: FR IT

fiorii Breuning, 1942b: 126

and (p.246)

etruscum etruscum Rossi, 1790: 147 (Lamia) E: IT

apenninum Depoli, 1926a: 25

apulum Depoli, 1926a: 25

beieri Pic, 1932d: 18

calabricum Breuning, 1942b: 126

femoratum Brullé, 1832: 259

fiorii Breuning, 1942b: 126

and (p. 247)

etruscum fiorii Breuning, 1942b: 126 E: IT

MUST BE (p. 247):

etruscum fiorii Breuning, 1942b: $126 \mathbf{E}$ : IT

NOTE:

According to Pesarini \& Sabbadini [2007].

58. PAGES 245, 250

PRINTED (P.245):

ciscaucasicum Jakovlev, 1900b: 59 E: ST

borodini Suvorov, 1915: 118

and: (p.250)

mokrzeckii Jakovlev, 1902: 148 E: UK

MUST BE (Р.245):

ciscaucasicum abramovi Lazarev, 2009: 14 E: ST (Taman)

ciscaucasicum ciscaucasicum Jakovlev, 1900b: 59 E: ST

borodini Suvorov, 1915: 118

ciscaucasicum mokrzeckii Jakovlev, 1902: 148 E: UK (Krym)

59. PAGE 270

PRINTED:

genus Choeromorpha Chevrolat, 1843: 613 type species Choeromorpha pigra Aurivillius, 1920

subgenus Choeromorpha Chevrolat, 1843: 613 type species Choeromorpha pigra Aurivillius, 1920
MUST BE:

genus Choeromorpha Chevrolat, 1843: 613 type species Choeromorpha pigra Chevrolat, 1843

subgenus Choeromorpha Chevrolat, 1843: 613 type species Choeromorpha pigra Chevrolat, 1843

60. PAGE 279

PRINTED:

genus Cereopsius Pascoe, 1862a: 344 type species Cereopsius exoletus Pascoe, 1862

MUST BE:

genus Cereopsius Pascoe, 1857b: 105 type species Cereopsius exoletus Pascoe, 1857

61. PAGE 279

PRINTED:

Falsapriona Pic, 1925c: 3 type species Falsapriona luteopubens Pic, 1925

MUST BE:

Falsopriona Pic, 1925c: 3 type species Falsopriona luteopubens Pic, 1925

62. PAGE 282

PRINTED:

Tibetobia szechenyana Frivaldszky, 1892

and

szechenyanus Frivaldszky, 1892a: 119 (Tibetobia)

MUST BE:

Tibetobia szechenyiana Frivaldszky, 1892

and

szechenyịanus Frivaldszky, 1892a: 119 (Tibetobia)

63. PAGE 281

PRINTED:

genus Hoplothrix Gahan, 1888a: 278 type species Hoplothrix simplex Gahan, 1888

MUST BE:

genus Haplothrix Gahan, 1888a: 278 type species Haplothrix simplex Gahan, 1888

NOTE:

According to the original publication.

64. PAGE 284

PRINTED:

genus Parepepeotes Breuning, 1938c: 182 type species Paraepepeotes breuningi Pic, 1935

affinis Breuning, 1938c: 183 A: UP ORR

albomaculatus Gahan, 1888a: 272 (Epepeotes) A: BT "North India"

breuningi Pic, 1935b: 16 (Paraepepeotes) A: SCH XIZ ORR

guttatus Guérin-Méneville, 1844: 242 (Monohamus) A: NP $\mathrm{SCH}$ "Himalaya" ORR

punctulatus Westwood, 1848: 12 (Monohammus) marmoratus Pic, 1925a: 19 (Monohammus) A: YUN ORR szetschuanicus Breuning, 1969e: 188 A: SCH

westwoodi Westwood, 1848: 12 (Monohammus) A: SD "Himalaya"

MUST BE:

genus Paraepepeotes Pic, 1935: 16 type species Paraepepeotes breuningi Pic, 1935

Parepepeotes Breuning, 1938c: 182 [unjustified emendation]

affinis Breuning, 1938c: 183 (Parepepeotes) A: UP ORR albomaculatus Gahan, 1888a: 272 (Epepeotes) A: BT "North India"

breuningi Pic, 1935b: 16 A: SCH XIZ ORR 
guttatus Guérin-Méneville, 1844: 242 (Monohamus) A: NP SCH "Himalaya" ORR

punctulatus Westwood, 1848: 12 (Monohammus)

marmoratus Pic, 1925a: 19 (Monohammus) A: YUN ORR szetschuanicus Breuning, 1969e: 188 ( Parepepeotes) A: SCH westwoodi Westwood, 1848: 12 (Monohammus) A: SD "Himalaya"

\section{PAGE 300}

PRINTED:

ressli Demelt, 1963: 150 A: TR

NOTE:

The taxon was wrongly attributed to the subgenus Oberea s. str., but in fact it belongs to Amaurostoma.

\section{PAGE 310 AND 311}

PRINTED (P.310):

diversiceps Pic, 1931f: 259 A: BT NP SD YUN ORR

lateraloides Breuning, 1958f: 300

rufoampliatus Breuning, 1958f: 300

subbicolor Breuning, 1958f: 300

and (p.311)

subbicolor Breuning, 1958f: 300 [RN] A: NP ORR

bicolor Pic, 1929a: 30 [HN]

MUST BE (p. 310):

diversiceps Pic, 1931f: 259 A: BT NP SD YUN ORR

lateraloides Breuning, 1958f: 300

rufoampliatus Breuning, 1958f: 300

The second case is correct.

\section{PAGE 819}

PRINTED:

Pic M. 1890e: [new taxa]. Bulletin de la Société Entomologique de France 1889: clxxvi-clxxvii. MUST BE:

Pic M. 1890e: [new taxa]. Bulletin de la Société Entomologique de France 1889: clxxv-clxxvi.

\section{PAGE 801}

PRINTED:

Müller J. 1907: Cerambycidae Dalmaciae. MUST BE:

Müller J. 1907: Cerambycidae Dalmatiae.

69. PAGE 801

PRINTED:

Mulsant E. 1847d: Description de deux coléoptères nouveaux, constituant chacun une nouvelle coupe générique. Annales des Sciences Physiques et Naturelles, d'Agriculture et d'Industrie de Lyon 10: 513-521, pl. 7.

MUST BE:

Mulsant E. 1847d: Description de deux coléoptères nouveaux, constituant chacun une nouvelle coupe générique. Annales des Sciences Physiques et Naturelles, d'Agriculture et d'Industrie de Lyon 10: 515-521, pl. 7.

\section{PAGE 883}

PRINTED:

Waterhouse C. O. 1889: Coleoptera. Pp. 121-131. Aitchison J. E. T.: The Zoology of the Afghan Delimitation Commission. The Transactions of the Linnean Society of London (2) 5 Zoology [1888-1894]: 53-142, pls. 6-14. MUST BE:

Waterhouse C. O. 1889: Coleoptera. Pp. 122-131. Aitchison J. E. T.: The Zoology of the Afghan Delimitation Commission. The Transactions of the Linnean Society of London (2) 5 Zoology [1888-1894]: 53-142, pls. 6-14.
ACKNOWLEDGEMENTS. I am very grateful to Alexey Gusakov and Andrey Ozerov (Zoological Museum of Moscow University), Andrery Lobanov (Zoological Institute, Sankt-Petersnurg) for providing me with the opportunity to study museums' materials. My special thanks to Karl Adlbauer, Alain Drumont, Martin Egger, Walter Grosser, Dan Heffern, Maxim Lazarev, Ivan Löbl, Tatsuya Niisato, Nobuo Ohbayashi, Sergey Saluk, Gianfranco Sama, Andrey Shapovalov, Ales Smetana, Petr Svacha, Szczepan Ziarko for valuable friendly consultations on many taxonomy problems, their own remarks and loaned specimens.

\section{References}

Bartenev A.F. 2004. Obzor vidov Zhukov-usachey (Coleoptera: Cerambycidae) fauny Ukrainy. [A review of the long-horned beetles species (Coleoptera: Cerambycidae) of the fauna of Ukraine] // Izvestiya Kharkovskogo Entomologicheskogo Obshchestva [The Kharkov Entomological Society Gazette]. Vol.11 [2003]. No.1-2. P.24-43. [in Russian].

Bartenev A.F. 2009. Zhuki-usachi Levoberezhnoy Ukrainy i Kryma. Kharkov, Kharkovskiy Natzionalnyy Universitet. [Longicornbeetles of Left-Bank Ukraine and Crimea. Kharkov: Kharkov National University]. 405p. [in Russian].

Danilevsky M.L. 2009. Species Group Taxa of Longhorned Beetles (Coleoptera,Cerambycidae) Described by N. N. Plavilstshikov and Their Types Preserved in the Zoological Museum of the Moscow State University and in the Zoological Institute of the Russian Academy of Sciences, St. Petersburg // Entomological Review. Vol.89. No.6. P.689-720.

Danilevsky M.L. \& Miroshnikov A.I. 1985. Zhuki-drovoseki Kavkaza (Coleoptera, Cerambycidae). Opredelitel. Krasnodar: Kubanskiy Selskokhozyaistvennyy Institut. 417 p., 10 pls. [in Russian].

Esjunin S.L. \& Kozminyh V.O. 1992. Materialy k faune zhestkokrylykh zakaznika "Troitzkiy" // Chlenistonogie okhranyaemykh territoriy Cheliabinskoy oblasti. Sverdlovsk. UrO AN SSSR. [Materials on the Coleoptera fauna of "Troitzky" reservation // Arthropoda of preserved territories of Cheljabinsk region. Sverdlovsk. Ural Branch of Ac. of Sc of the USSR]. P.59-67. [in Russian]

Gfeller W. 1972. Cerambycidae (Coleoptera) der Tuerkei. Persienexpedition 1970 der Herren Dr. h.c. Wittmer und U. v. Bothmer // Mitteilungen der Entomologischen Gesellschaft Basel. (N.F.) Bd.22. No.1. S.1-8.

Grebennikov V.V., Gill B.D. \& Vigneault R. 2010. Trichoferus campestris (Faldermann) (Coleoptera: Cerambycidae), an Asian wood-boring beetle recorded in North America // Coleopterists Bulletin. Vol.64. No.1. P.13-20.

Han Ch. \& Niisato T. 2009: Clytine Beetles of the genus Sclethrus Newman (Coleoptera, Cerambycidae) // Special Bulletin of the Japanese Society of Coleopterology, Tokyo. Vol.7. P.117-126.

Hayashi M. \& Villiers A. 1987. Revision of the Asian Lepturinae (Coleoptera: Cerambycidae) With special reference to the type specimens' inspection. Part II // Bulletin of Osaka Jonan Women's Junior College. Vol.22. P.1-20. Pls.1-3.

Heyrovsky L. 1934. Druhý přispěvek ke známosti tribu Lepturini. (Col. Cerambycidae) // Časopis Československé společnosti entomologické. Vol.31. P.8-12.

Inokaitis V. 2004. Naujos ir retos Lietuvos entomofaunos vabalu (Coleoptera) rusys, aptiktos 2000-2003 metais. New and rare for the Lithuanian fauna Coleoptera species found in 20002003 // New and Rare for Lithuania Insect Species Records and Descriptions. Vol.16. P.7-10.

Inokaitis V. 2009. Rare and very rare for the Lithanian fauna Coleoptera species found in 2004-2009// New and rare for Lithuania insect species. Records ans description. Vol.21. P.40-44.

Isaev A.Yu. 2007. Opredelitel zhestkokrulykh Srednego Povolzhya (chast III. Polyphaga, Phytophaga). Seriya "Priroda Ulyanovskoy oblasti”. [A key for beetles of Middle Volga (part III. Polyphaga, 
Phytophaga). Serie "Nature of Ulianovsk Region"]. No.14. Ulianovsk. Publishing house "Vektor-C". P.1-225 [in Russian].

Isaev A.Yu., Egorov L.V. \& Egorov K.A. 2004. Zhestkokrylye (Insecta, Coleoptera) lesostepi Srednego Povolzhya. Katalog. [Beetles (Insecta, Coleoptera) of forest-steppe of Middle Volga. Catalogue] Ulianovsk. 72 p. [in Russian].

Isaev A.Yu., Magdeev D.V. 2003. Fauna Zhukov-usachey (Coleoptera, Cerambycidae) lesostepnoy zony Povolzhya // Issledovaniya $\mathrm{v}$ oblasti biologii i metodiki ee prepodavaniya. Mezhvuzovskiy sbornik nauchnykh trudov k 100-letiyu D.N. Florova, vyp. 3, ch. 1. [Fauna of Longicorn-beetles (Coleoptera, Cerambycidae) of forest-steppe zone of Volga valley // Investigations in the field of biology and methods of its teaching. Interinstitutes collection of transactions to the $100^{\text {th }}$ anniversary of D.N. Flerov, 3(1)] Samara. P.290-300 [in Russian].

Kaliuzhnaja N.S., Komarov E.V. \& Cherezova L. B. 2000. Zhestkokrylye nasekomye Nizhnego Povolzhya. [Coleoptera of lower Volga river]. Volgograd. 204 p. [in Russian].

Kostin I.A. 1968. Rasprostranenie drovosekov (Coleoptera, Cerambycidae) listvennykh porod v Kazakhstane // Nasekomye vrediteli selskogo i lesnogo khozyaistva Kazakhstana. Trudy Instituta Zoologii, Akademiya nauk Kaz. SSR. [Distribution of Cerambycidae (Coleoptera) in the leaf-bearing woods in Kazakhstan // Pest Isects of Agriculture and Forests of Kazakhstan. Proceedings of the Institute of Zoology, Academy of Sciences of Kazakhstan SSR]. Vol.30. P.184-197 [in Russian].

Kostin I.A. 1973. Zhuki-dendrofagi Kazakhstana (koroedy, drovoseki, zlatki). Alma-Ata: Akademiya Nauk Kazakhskoy SSR. 288 p.

Kryzhanovsky O.L. 1974. 35. Sem. Cerambycidae - drovoseki ili usachi // Nasekomye i kleshchi — vrediteli selskokhozyaistvennykh kultur. [35. Fam. Cerambycidae - timber beetlest or longicorn beetles // Insects and ticks - pests of agricultural crops]. Leningrad: Nauka. P.139-157 [in Russian].

Lobanov A. L., Danilevsky M. L. \& Murzin S. V. 1981. Sistematicheskiy spisok usachei (Coleoptera, Cerambycidae) fauny SSSR. I // Entomologicheskoe Obozrenie. Vol.60. P.784-803 [in Russian].

Löbl I. \& Smetana A. (eds.). 2010. Catalogue of Palaearctic Coleoptera. Vol.6. Chrysomeloidea. Stenstrup. Apollo Books. 924pp.

Magdeev D.V. 1996. Zhuki-usachi (Cerambycidae, Coleoptera) // Flora i fauna zapovednikov. Vyp.61. Bespozvonochnye Zhigulevskogo zapovednika. Moscow. P.39-47 [in Russian].

Magdeev D.V. 2003. Fauna Zhukov-usachey (Coleoptera, Cerambycidae) Samarskoy oblasti // Kraevedchiskie zapiski, XI. Samarskiy oblastnoy istoriko-kraevedchiskiy muzey. [Fauna of Longicorn-Beetles (Coleoptera, Cerambycidae) of Samara Region. // Local history notes, XI. Samara Regional Local History Museum]. Samara: Fine Design.P.202-208 [in Russian].

Martynov V.V. \& Pisarenko T.A. 2004. Ecologo-faunisticheskiy obzor Zhukov-usachey (Coleoptera: Cerambycidae) yugo-vostochnoy Ukrainy // Izvestiya Kharkovskogo entomologicheskogo obshchestva. [A review of the fauna and ecology of the longhorned beetles (Coleoptera: Cerambycidae) of southeast Ukraine // The Kharkov Entomological Society Gazette]. Vol.11.(2003). No.1-2. P.44-69 [in Russian].

Mikhailov Yu.E. 1999. Nasekomye muzeya-zapovednika "Arkaim”. Zhestkokrylye: vidovoy sostav i zametki po structure populyatziy. Prirodnye sistemy Yuzhnogo Urala. Cheliabinsk. Cheliabinskiy gos. universitet. [Insects of "Arkaim" museum-natural reserve. Beetles: species composition and notes on the structure of populations // Natural systems of South Urals]. Cheljabinsk. Cheljabinsk University. P.221-248 [in Russian].

Miroshnikov A.I. 1998. Novaya klassifikacia zhukov-drovosekov kompleksa Anoplodera triby Lepturini (Coleoptera, Cerambycidae) fauny golarktiki. I // Entomologicheskoe Obozrenie.
Vol.77. No.2. P.384-421.

Muraj X. 1960. Inventarizimi i fam. Cerambycidae ne vendin tone. Quelques Cerambycides en Albanie // Bull Univ. Shtet. Tiranes. Ser. Shkencat nat. Vol.14. No.4. P.137-141.

Naumov R.V. 1994. Zhuki-usachi (Coleoptera, Cerambycidae) Ulyanovskoy oblasti. Ser. "Priroda Ulyanovskoy oblasti". [Longicorn-beetles (Coleoptera, Cerambycidae) of Ulianovsk region. Ser. "The Nature of Ulianovsk Region"]. 5. Ulianovsk. P.43-46 [in Russian].

Negrobov S.O., Tzurikov M.N., Logvinovsky V.D., Fomichev A. I., Prokin A.A. \& Gilmutdinov K.S. 2005. Otryad Coleoptera. Kadastr bespozvonochnykh Voronezhskoy oblasti. [Order Coleoptera. Cadastre of Invertebrata of Voronezh region]. Voronezh. P.534-673 [in Russian].

Niisato T. 2002. New locality of Salpinia laosensis (Coleoptera, Cerambycidae), with a note on its systematic position // Elytra. Vol.30. No.1. P.262.

Niisto T. 2007. Subfamily Cerambycinae Latreille, 1804 // Ohbayashi N. \& Niisato T. (eds). Longicorn beetles of Japan. Kanagawa: Tokai Univ. Press. P.424-512

Ohbayashi N. \& Niisato T. 2009. Review of the Pyrocalimma Generic-Group sensu Hayashi \& Villiers, 1997, with descriptions of new Genus and two new species (Coleoptera, Cerambycidae, Lepturinae) // Longicornists, Special Bulletin of the Japanese Society of Coleopterology. No.7. Tokyo. P.139-167.

Pisarenko T.A. 1999. Osoblivosti fauni rodini vysachiv (Coleoptera, Cerambycidae) promislovikh i zapovidnikh rayoniv pivdennoskhidnoy Ukraini // Naukoviy Visnik. Suchasna ekologia i problemi stalogo rozvitku suspilstva. Vip.97. Lvov. P.149-155 [in Ukrainian]

Plavilstshikov N.N. 1965, 75. Sem. Cerambycidae — zhukidrovoseki, usachi // Opredelitel nasekomykh Evropeyskoy chasti SSSR, t.2, zhestkokrylye i veerokrylye. [75-th Fam. Cerambycidae - Timber Beetles, Longicornes // A Key to Insects of the European Part of the USSR, v. 2, Coleoptera and Strepsiptera]. M.-L.: Nauka. P.389-419 [in Russian].

Romadina K.G. 1954. Drevogryzushchie lichinki Zhukov-usachey (Cerambycidae) doliny reki Urala // Trudy Zoologicheskogo Instituta akademii nauk SSSR. [Woodboring Longicorn (Cerambycidae) beetle-larvae of Ural river valley // Archives of the Zoological Institute of the Academy of Sciences of the USSR]. Vol.16. P.211-228 [in Russian].

Sama G., Rapuzzi P. \& Kairouz A. 2010. Catalogue commenté des Cerambycidae du Liban. An annotated catalogue of the Cerambycidae of Lebanon (Insecta Coleoptera Cerambycidae) // Quaderno di Studi e Notizie di Storia Naturale della Romagna. Vol.30. P.131-201.

Schultze W. 1920. Eights contribution to the Coleoptera fauna of the Philippines // Philippine Journal of Science. Vol.16. P.191-203. 2 pls.

Shapovalov A.M., Nemkov V.A., Rusakov A.V. \& Shovkun D.F. 2006. Zhuki-usachi (Coleoptera, Cerambycidae) Orenburgskoy oblasti. // Vestnik Orenburgskogo gosudarstvennogo universiteta. Orenburg: Izd-vo OGU. [Longicorn-beetles (Coleoptera, Cerambycidae) of Orenburg Region. - Vestnik of Orenburg State University]. Vol.4. No.54. P.105-109. [in Russian].

Yen Chia-hsien 1932. A new species of Cerambycidae from Kwangsi // Peking Natural History Bulletin. Vol.7. No.2. P.165-166.

Zagaikevich I.K. 1979. Nekotorye aspekty khorologii usachey (Coleoptera, Cerambycidae) fauny Ukrainy. - VII Mezhdunarodniy simpozium po entomofaune Sredney Evropy. Materialy. Leningrad, 19-24 sentiabria 1977. P.195-197.

Zagaikevich I.K. 1991. Taksonomiya i ekologiya usachey. Kiev: Naukova Dumka. 178 p. [in Russian].

Zhuravlev S.M. 1914. Materialy k faune zhukov Uralskoy oblasti // Trudy Russkogo Entomologicheskogo Obshchestva. Vol.41. No.3. P.33-61. 